\title{
Determination of Significant Baseline Widal Titre amongst Health Personnel \& General Population of Ajmer City
}

\author{
Laxman Ram Mohanpuria', Priyam Sharma ${ }^{2}$, Prateek Kamble ${ }^{1}$, Mohit Sharma ${ }^{3}$, \\ Geeta Parihar ${ }^{4}$, Mahima Sharma ${ }^{5}$ \\ ${ }^{1}$ Senior Resident, ${ }^{2}$ M.Sc. (Microbiology), ${ }^{4}$ Professor and Head, Department of Microbiology,

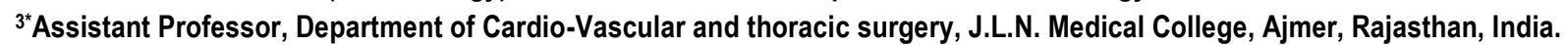 \\ ${ }^{5}$ Senior Demonstrator, Department of Physiology, R.U.H.S. Medical College, Jaipur, Rajasthan, India.
}

\begin{abstract}
Background: Enteric Fever is the most infectious disease on global scale and endemic in all parts of India. In a developing country like India laboratory diagnosis of enteric fever relies heavily on serological tests such as widal test. Knowledge of prevalent endemic titre in a region needs to be periodically updated to interpret the significance of the titre as to patient is indeed suffering from enteric fever or not. The present study has been undertaken to evaluate the baseline antibody titre for $\mathrm{O}, \mathrm{H}$ antigens of Salmonella Enterica, serovar Typhi and $\mathrm{AH}$, $\mathrm{BH}$ antigen of Salmonella Enterica, serovar Paratyphi among health personnel and general adult population of Ajmer (Rajasthan).
\end{abstract}

Aim and objectives: To evaluate the significant endemic baseline titre of Ajmer city using quantitative Widal test to suggest the cut off value for interpreting a positive widal test. To compare the endemic baseline titre amongst the Health care providers and General Population.

Material and methods: A total number of 600 healthy volunteers and 200 medical personnel working in Jawahar Lal Nehru Medical College, Ajmer were screened during period of study from $1^{\text {st }}$ April 2014 to $31^{\text {st }}$ December 2015. Non repetitive samples were collected from healthy adults aged 18 year to 70 year.

Results and conclusions: Out of 600 screened samples for healthy volunteers $61 \%$ were males and $39 \%$ were females. The frequency of positive results was $43.67 \%$. The agglutinins to S. Typhi were the most prevalent among the sera of various dilutions (33.16\% for ' $\mathrm{O}$ ' antigen and $43.33 \%$ for ' $\mathrm{H}$ ' antigen) which was tested. The levels of agglutinins for Salmonella

\section{INTRODUCTION}

Enteric Fever is one of the most infectious diseases on a global scale and endemic in all parts of India. Typhoid fever has important socio-economic impact because, most of the time, several months are necessary for a patient to recover and be able to work again. So accurate diagnosis of typhoid fever at an early stage is important not only for etiological diagnosis, but also to identify individuals that may serve as a potential carrier, who may be responsible for acute typhoid fever outbreaks.

In India the disease is endemic with an incidence which ranges from $102-2219 / 100,000$ population. ${ }^{1}$ Hospital based studies and outbreak reports from India indicates that occurrence rate of enteric fever has risen sharply in recent years. ${ }^{2}$ Enteric fever is endemic in developing countries like India and it continues to be one of the major public health problems. ${ }^{3}$ Widal test is an alternative to the Microbial culture, which is commonly used for the diagnosis of enteric fever ever since its introduction 100 years back. ${ }^{4}$ paratyphi $\mathrm{AH}$ and paratyphi $\mathrm{BH}$ were low (only $1.16 \%$ for $\mathrm{AH}$ and $1.83 \%$ for $\mathrm{BH}$ antigen respectively). Out of 200 samples of health personnel screened $69 \%$ were males and $31 \%$ were females. The frequency of positive results was $45.5 \%$. The agglutinins to $\mathrm{S}$. Typhi were the most prevalent among the sera of various dilutions $(33.16 \%$ for ' $\mathrm{O}$ ' antigen and $44.5 \%$ for ' $\mathrm{H}$ ' antigen) which were tested. The levels of agglutinins for Salmonella paratyphi $\mathrm{AH}$ and paratyphi $\mathrm{BH}$ were low (only $4.0 \%$ for $\mathrm{AH}$ and $1.5 \%$ for $\mathrm{BH}$ antigen respectively). Based on the above results, it has been recommended that cut-off titre of $1: 80$ for anti-O antibodies and of 1:120 for the anti- $\mathrm{H}$ antibodies may be considered as diagnostic for enteric fever in Ajmer region of Rajasthan, India.

Keywords: Enteric fever, Salmonella, Widal titre.

\section{*Correspondence to:}

Dr. Mohit Sharma, Department of Cardio-Vascular and thoracic surgery, J.L.N. Medical College, Ajmer, Rajasthan, India. Email: aries.mohit@gmail.com

Article History:

Received: 21-04-2016, Revised: 27-04-2016, Accepted: 30-05-2016

\begin{tabular}{|l|c|}
\hline \multicolumn{2}{|c|}{ Access this article online } \\
\hline Website: & Quick Response code \\
\cline { 2 - 2 } www.ijmrp.com & \\
\hline DOl: & \\
10.21276/ijmr. 2016.2 .3 .037 & \\
\hline
\end{tabular}

In the endemic areas, the healthy people may contain antibodies which are capable or reacting up to a variable titre in the Widal test, due to a past exposure, TAB vaccination and cross reacting antigens. Therefore it varies widely from place to place and is referred to as the baseline titre of that area. The isolation of the organism from blood, bone marrow or stool is required to confirm the diagnosis. ${ }^{5-7}$

Although the isolation of Salmonella Typhi on blood culture remains the gold standard for diagnosis of typhoid fever, it is time consuming, requires elaborate laboratory equipment and a level of technical expertise which may not be present in resource-poor laboratories.

Even under the best conditions, there may be failure to isolate the organism, especially after antimicrobial treatment has been started. Culture of bone marrow is more sensitive, but the procedure is invasive, stool cultures are positive in only $30 \%$ of patients with the acute illness. ${ }^{7,8}$ 
The illness begins with mounting fever, headache, vague abdominal pain and constipation, which may be followed by appearance of rashes. ${ }^{9}$ During the third week, the patient reaches a state of prolonged apathy, toxemia, delirium disorientation and/or coma followed by diarrhea. If left untreated, it can lead to complications affecting various organ systems. ${ }^{10}$

Typhoid fever is a major health problem in developing countries where safe water supplies and adequate sewage disposal are often lacking. ${ }^{11}$ For the diagnosis of typhoid fever during first week blood culture is most reliable test, but the blood culture is expensive, time consuming, cumbersome, lack of facilities for routine culture unavailable, inhibition of growth due to improper \& inadequate medication/Self-medication and minimum culture positivity rate. ${ }^{12}$

An optimal diagnosis of enteric fever on clinical ground alone is very difficult because of the nonspecific sign \& symptoms of the disease. In a developing country like India the bacterial culture facilities are often unavailable. The Widal test continues to be the most simple and popular test in the presumptive diagnosis of typhoid fever. ${ }^{13}$ The Widal test measures agglutinating antibodies against the lipo-polysaccharide $\mathrm{O}$, flagellar proteins $\mathrm{H}$ antigen of Salmonella Typhi \& flagellar proteins $\mathrm{H}$ antigen of paratyphi $\mathrm{A}$ \& B. ${ }^{13,14}$ In endemic countries like India, interpretation of Widal test depends upon the baseline titre which is prevalent amongst the healthy individuals in a particular geographical area. ${ }^{15}$ The baseline titre among the healthy population of different areas differs substantially \& this depends upon the endemicity of the enteric fever cases in each area which keeps on changing over time.$^{8}$ Knowledge of prevalent endemic titre in a region needs to be periodically updated to interpret the significance of the titre as to the patient is indeed suffering from enteric fever or not. ${ }^{3}$ Antibody titre beyond the cut off value should be regarded as significantly elevated titers which may be used for diagnosis in an appropriate clinical setting. ${ }^{16}$

Few limitations of Widal test are; low reliability, low sensitivity \& specificity even it can't distinguish between current infection/past infection / vaccination. False positive result may lead to over diagnosis / over treatment of typhoid fever, furthermore antibody titre may be high in healthy individuals in the presence of cross reacting antigens such as brucellosis, chronic liver disease, dengue fever, endocarditis, healthy carrier state, malaria and other Enterobacteriaceae infections ( $>40 \%) .17-19$

\section{AIM AND OBJECTIVES}

Our aim was to evaluate the significant endemic baseline titre of AJMER city using quantitative Widal test to suggest the cut off value for interpreting a positive Widal test. To compare the endemic baseline titre amongst the Health care providers and General Population.

\section{MATERIAL AND METHODS}

This was a community based, cross sectional study; conducted in the Department of Microbiology, Jawahar Lal Nehru Medical College and Associated Group of Hospitals, Ajmer from $1^{\text {st }}$ April 2014 to 31st December 2015. The study protocol and objectives were duly explained to the volunteers of both sexes and of the respective age groups which ranged from 18-70 years, nonrepetitive blood samples were collected.

The population of Ajmer city according to 2011 census was 5 , 42,580 Approximately 5, 50,000. The incidence of enteric fever was 1767 (calculated from April 2013 to March 2014). A total of 600 healthy and 200 medical volunteers were screened for the period of one year i.e. from $1^{\text {st }}$ April 2014 to $31^{\text {st }}$ March, 2015 for the agglutinins against the Salmonella enterica, subspecies enterica serotypes, Typhi, paratyphi A and paratyphi B by the Widal Agglutination Test.

Inclusion Criteria

- They should be Residents of Ajmer since last three years.

- They should have no history of Fever since last six months.

- They should not have been immunized against enteric fever recently.

\section{Exclusion Criteria}

- Immunized for enteric fever.

- Above or below the considered age group.

We used the standard laboratory method i.e. serial dilution of tube agglutination for Widal test.

Table A: For Healthy Volunteers: Base Line Demographics of Selected Cases $(N=600)$

\begin{tabular}{|c|c|c|c|}
\hline \multicolumn{2}{|c|}{ VARIABLE } & NUMBER & $\%$ \\
\hline \multicolumn{4}{|c|}{ 1. AGE DISTRIBUTION } \\
\hline A. & $18-40$ (YEAR) & 395 & $65.83 \%$ \\
\hline & $>40$ (YEAR) & 205 & $34.17 \%$ \\
\hline \multicolumn{4}{|c|}{ 2. SEX DISTRIBUTION } \\
\hline & MALE & 366 & $61 \%$ \\
\hline & FEMALE & 234 & $39 \%$ \\
\hline \multicolumn{4}{|c|}{ 3. WIDAL STATUS } \\
\hline A. & POSITIVE AGGLUTININS ( $\geq 1: 20)$ & 262 & $43.67 \%$ \\
\hline \multirow{3}{*}{\multicolumn{4}{|c|}{$\begin{array}{l}\text { B. NEGATIVE AGGLUTININS }(\leq 1: 20) \\
\text { 4. DISTRIBUTION OF SAMPLES }\end{array}$}} \\
\hline & & & \\
\hline & \\
\hline & ANTI 'O' ANTIGEN & 199 & $33.16 \%$ \\
\hline & ANTI 'H' ANTIGEN & 260 & $43.33 \%$ \\
\hline \multicolumn{4}{|c|}{ B. PARATYPHI A } \\
\hline & ANTI 'H’ ANTIGEN & 25 & $4.16 \%$ \\
\hline \multicolumn{4}{|c|}{ C. PARATYPHI B } \\
\hline & ANTI 'H' ANTIGEN & 11 & $1.83 \%$ \\
\hline
\end{tabular}


Table B: Results of Widal Test in Selected Cases of Healthy Volunteers

\begin{tabular}{lccccc}
\hline Antigen & $\begin{array}{c}\text { No.of positive } \\
\text { samples (\%) }\end{array}$ & Dilution (1:20) & Dilution (1:40) & Dilution (1:60) & Dilution (1:80) \\
\hline S.Typhi '0' & $199(33.16 \%)$ & $51(8.5 \%)$ & $130(21.66 \%)$ & $16(2.66 \%)$ & $2(0.4 \%)$ \\
S.Typhi 'H' & $260(43.4 \%)$ & $62(10.33 \%)$ & $18(3 \%)$ & $172(28.66 \%)$ & $8(1.4 \%)$ \\
S.Paratyphi AH & $25(4.2 \%)$ & $17(2.9 \%)$ & $8(1.33 \%)$ & - & - \\
S.Paratyphi BH & $11(1.9 \%)$ & $11(1.9 \%)$ & - & - & - \\
\hline
\end{tabular}

Table C: For Medical Personnel: Base Line Demographics of Selected Cases ( $\mathrm{N}=\mathbf{2 0 0}$ )

\begin{tabular}{|c|c|c|c|}
\hline \multicolumn{2}{|c|}{ VARIABLE } & NUMBER & $\%$ \\
\hline \multicolumn{4}{|c|}{ 1. AGE DISTRIBUTION } \\
\hline A. & 18-40 (YEAR) & 165 & $82.5 \%$ \\
\hline & $>40$ (YEAR) & 35 & $17.5 \%$ \\
\hline \multicolumn{4}{|c|}{ 2. SEX DISTRIBUTION } \\
\hline & MALE & 138 & $69 \%$ \\
\hline & FEMALE & 62 & $31 \%$ \\
\hline \multicolumn{4}{|c|}{ 3. WIDAL STATUS } \\
\hline & POSITIVE AGGLUTININS ( $\geq 1: 20)$ & 91 & $45.5 \%$ \\
\hline & NEGATIVE AGGLUTININS ( $\leq 1: 20)$ & 109 & $54.5 \%$ \\
\hline \multicolumn{4}{|c|}{ 4. DISTRIBUTION OF SAMPLES } \\
\hline \multicolumn{4}{|c|}{ A. S.TYPHI } \\
\hline & ANTI 'O’ ANTIGEN & 68 & $34.0 \%$ \\
\hline & ANTI 'H' ANTIGEN & 89 & $44.5 \%$ \\
\hline \multicolumn{4}{|c|}{ B. PARATYPHI A } \\
\hline & ANTI 'H' ANTIGEN & 8 & $4.0 \%$ \\
\hline \multicolumn{4}{|c|}{ C. PARATYPHI B } \\
\hline & ANTI 'H' ANTIGEN & 3 & $1.5 \%$ \\
\hline
\end{tabular}

Table D: Result of Widal Test in Selected Cases for Medical Personnel

\begin{tabular}{lccccc}
\hline Antigen & $\begin{array}{c}\text { No.of positive } \\
\text { samples (\%) }\end{array}$ & Dilution (1:20) & Dilution (1:40) & Dilution (1:60) & Dilution (1:80) \\
\hline S.Typhi 'O' & $68(34 \%)$ & $18(9.0 \%)$ & $45(22.5 \%)$ & $4(2 \%)$ & $1(0.5 \%)$ \\
S.Typhi 'H' & $89(44.5 \%)$ & $22(11 \%)$ & $10(5 \%)$ & $54(27 \%)$ & $3(1.5 \%)$ \\
S.Paratyphi AH & $8(4 \%)$ & $5(2.5 \%)$ & $3(1.5 \%)$ & - & - \\
S.Paratyphi BH & $3(1.5 \%)$ & $3(1.5 \%)$ & - & - & - \\
\hline
\end{tabular}

\section{OBSERVATIONS}

As mentioned in Table-A, $65.83 \%$ of study participants belong to age group $18-40$ years and $34.17 \%$ were in age group of $>40$ years. Youngest volunteer was 18 years of age and oldest volunteer was 69 years of age. Out of 600 participants, 366 $(61.0 \%)$ were male and $234(39 \%)$ were females. Out of 600 healthy volunteers $262(43.67 \%)$ samples were positive for the agglutinins ( $\geqq 1: 20)$ whereas $338(56.33 \%)$ samples did not show aggluntinins $(\leq 1: 20)$. The agglutinins to $\mathrm{S}$. Typhi were the most prevalent among the sera of various dilutions $(33.16 \%$ for ' $O$ ' antigen and $43.33 \%$ for the ' $\mathrm{H}$ ' antigen) which were tested. The levels of agglutinins for Salmonella paratyphi $\mathrm{AH}$ and paratyphi $\mathrm{BH}$ were low (only $4.16 \%$ for $\mathrm{AH}$ and $1.83 \%$ for $\mathrm{BH}$ antigen respectively).

Table-B depicts the distribution of 199 samples with the anti $O$ titre of $\geq 1: 20$ to the Salmonella enterica serotype, Typhi showed that 51 samples (8.5\%) had a titre of $1: 20,130$ samples $(21.66 \%)$ had a titre of $1: 40$ and 16 samples $(2.66 \%)$ had a titre of $1: 60$, while only 2 samples $(0.4 \%)$ had the highest titre of $1: 160$. Similarly, among the 260 samples which showed the anti $\mathrm{H}$ titre to the Salmonella enterica serotype, Typhi 62 samples $(10.33 \%)$ had a titre of 1:20, 18 samples had a titre of $1: 40,172$ samples
(28.66\%) had a (3.0\%) titre of $1: 60$ and only 8 samples $(1.4 \%)$ showed the highest dilution titre. Altogether, 25 samples (4.2\%) showed agglutination titre against the $\mathrm{H}$ antigen of the Salmonella enterica serotype paratyphi $A$ among which 17 samples (2.9\%) had a titre of $1: 20$ rest of the 8 samples (1.33\%) had a titre of 1:40. Only 11 samples (1.9\%) had an anti $\mathrm{H}$-titre of $1: 20$ for the Salmonella Enterica serotype, paratyphi B.

200 medical personnel were only screened in this category as the cut-off titre was nearly similar to that of the healthy population and also the test was to be conducted within a period of one year i.e. from 1st April 2014 to 31st December 2015, therefore considering time limit of study only 200 samples were screened. As mentioned in table $82.5 \%$ of patients belong to age group $18-40$ years. $17.5 \%$ were in age group of $\geq 40$ years. Youngest individual was 20 years of age and oldest individual was 65 years of age. Out of 200 cases, $138(69 \%)$ were male and $62(31 \%)$ were females. Out of 200 medical personnel 91 (45.5\%) samples were positive for the agglutinins ( $\geq 1: 20)$ whereas $109(54.5 \%)$ samples did not show aggluntinins ( $\leq 1: 20)$. Table-C shows the distribution of Salmonella agglutinins titre in the 91 sera of the medical personnel. The agglutinins to $\mathrm{S}$. Typhi were the most prevalent among the sera of various dilutions $(33.16 \%$ for ' $\mathrm{O}$ ' antigen and $44.5 \%$ for the ' $\mathrm{H}$ ' 
antigen) which were tested. The levels of agglutinins for Salmonella paratyphi $\mathrm{AH}$ and paratyphi $\mathrm{BH}$ were low (only $4.0 \%$ for $\mathrm{AH}$ and $1.5 \%$ for $\mathrm{BH}$ antigen respectively).

Table-D depicts the distribution of 68 samples with the anti $O$ titre of $\geq 1$ : 20 to the Salmonella Enterica serotype, Typhi showed that 18 samples $(9.0 \%)$ had a titre of $1: 20,45$ samples $(22.5 \%)$ had a titre of $1: 40$ and 4 samples $(2.0 \%)$ had a titre of $1: 60$, while only 1 sample $(0.5 \%)$ had the highest titre of $1: 160$. Similarly, among the 89 samples which showed the anti-H titre to the Salmonella Enterica serotype, Typhi 22 samples (11.0\%) had a titre of 1:20, $10(5.0 \%)$ samples had a titre of $1: 40,54$ samples $(27.0 \%)$ had a titre of $1: 60$ and only 3 samples $(1.5 \%)$ showed the highest dilution titre. Altogether, 8 samples $(4.0 \%)$ showed agglutination titre against the $H$ antigen of the Salmonella enterica serotype paratyphi $A$ among which 5 samples $(2.5 \%)$ had a titre of $1: 20$ and the rest of the 3 samples $(1.50 \%)$ had a titre of $1: 40$. Only 3 samples $(1.5 \%)$ had an anti $\mathrm{H}$-titre of $1: 20$ for the Salmonella enterica serotype, paratyphi B.

\section{DISCUSSION}

In the developing countries, such as the Indian subcontinent, many clinics and hospitals do not have a ready access to the blood culture method, thus making the Widal tube agglutination test the most common alternative laboratory procedure for the diagnosis of enteric fever. The serological diagnosis relies classically on the demonstration of the rising titre of the antibodies in paired samples, 10 to 14 days apart. For practical purposes, the treatment decision must be made on the basis of the results which are obtained with a single acute phase sample. The cut off titre in a particular population depends on the background level of the typhoid antibodies and the level of the typhoid vaccination, which may vary with time. ${ }^{14}$

Out of total 800 serum samples, about $44.12 \%$ sample showed antibodies against Salmonella antigens with varying antibody titre. This may be due to the higher endemicity of enteric fever in Ajmer. This may also be due to the repeated subclinical infections with either of Escherichia, Shigella, Citrobacter or Proteus species which shared common $\mathrm{O}$ or $\mathrm{H}$ antigens with Salmonella spp. Variable titre with both $\mathrm{O}, \mathrm{H}$ and $\mathrm{AH}$ or $\mathrm{BH}$ antigens was found, this might be due to the cross infection of Salmonella Enterica serotype Typhi and Salmonella Enterica serotype paratyphi A and lor $\mathrm{B}$. Lower antibody titre against $\mathrm{AH}$ and $\mathrm{BH}$ antigens highlighted the lower endemicity of paratyphi infection compared with Typhi infection, and/or low antibody response against paratyphi infection.

This study clearly showed that in an endemic area such as Ajmer, S. Enterica serotype Typhi agglutinins against both $\mathrm{H}$ and $\mathrm{O}$ antigens may be present in the normal population at titers up to or greater than 1:80. Out of the total serum samples, we found $O$ and $\mathrm{H}$ agglutinin titre of $\geq 1: 120$ in $10.4 \%$ and $10.6 \%$ of blood donors respectively. $\mathrm{H}$ agglutinin at a titre of $1: 240$ was found in $4.9 \%$ of blood donors. This presence of significant agglutinin titre in healthy individuals decreases the specificity of the Widal test, leading to misdiagnosis and mismanagement of the patient. In a similar type of study, $15 \%$ of the individuals had anti-O antibody titers of $\geq 1: 80$ and $16 \%$ had anti- $\mathrm{H}$ antibody titers of $\geq 1: 160$.

A study by Pang and Puthucheray ${ }^{2}$ found, $\mathrm{O}$ and $\mathrm{H}$ agglutinins titers of $\geq 1: 160$ in $5 \%$ and $2 \%$ of non-infected individuals, they found geographical variation of both $\mathrm{O}$ and $\mathrm{H}$ Widal agglutinin titre. $\mathrm{H}$ agglutinin titer varied greatly compared with $\mathrm{O}$ agglutinin titre. The currently used cutoff value for anti-H titre against $\mathrm{S}$. Enterica serotype paratyphi $A$ in Ajmer is $\geq 1: 80$. Our study found that $3.7 \%$ of individuals had anti-H agglutinin titre of $\geq 1: 80$ to Salmonella Enterica serotype paratyphi A. Our study found that $\mathrm{AH}$ agglutinin titre is increasing in the population as compared with the similar study done in Nepal. ${ }^{20}$ This may be due to an increase in general population antibody levels caused by the changing pattern of Salmonella Enterica serotype paratyphi A in the community. The seroprevalence of Salmonella enterica serotype paratyphi B was found quiet low in the whole studied population.

The percentage of samples showing agglutination with both 0 and $\mathrm{H}$ antigens at a titre of $1: 80$ were $8.2 \%$, whereas only $2.7 \%$ of the total samples were positive with both $\mathrm{O}$ and $\mathrm{H}$ agglutinin at a titre of $1: 160$. This showed that when both $\mathrm{O}$ and $\mathrm{H}$ antigens are considered together, titre of $1: 160$ is sufficient to make the presumptive diagnosis of enteric fever. From the study done in Kathmandu by Pokhrel et al.20 found that $12 \%$ of individuals had an anti- $O$ titre of $1: 80$ and anti- $H$ titre of $1: 160$. Based on this they recommended cut off levels against $\mathrm{S}$. Enterica serotype Typhi to $>1: 80$ for anti - $\mathrm{O}$ and $>1: 160$ for anti- $\mathrm{H}$ titres for Nepal. From a similar type of study by Zailani et al21 the baseline and significant titre to $\mathrm{S}$. Typhi/paratyphi for both $\mathrm{O}$ and $\mathrm{H}$ antibody is $1: 80$ and $\geq 1: 160$ respectively in another study in Nigeria. ${ }^{22}$ In this study we found that about $10.5 \%$ of individuals had both $\mathrm{O}$ and $\mathrm{H}$ agglutinin titre of 1:120. Based on this finding we recommend that it will be more appropriate to change currently used cut off titre levels against $S$. Enterica serotype Typhi for $O(1: 80)$ and $H$ (1:120) titers for Ajmer.

A study in the Garhwal region ${ }^{23}$ concludes that the current baseline titre for the diagnosis of typhoid fever is $1: 40$ for the anti$\mathrm{O}$ agglutinins and that it is $1: 80$ for the anti- $\mathrm{H}$ agglutinins. Based on this finding, we have set our own laboratory guidelines of the $\mathrm{H}$ and $O$ agglutinin Widal titres of $1: 120$ and $1: 80$ as being of diagnostic significance. The baseline anti- $\mathrm{H}$ agglutinin titre of the paratyphoid $A$ and $B$ groups was found to be $1: 20$ in $2.5 \%$ and $1.3 \%$ of the healthy population respectively, which suggested that the paratyphoid groups were less prevalent in this area as compared to S. Typhi.

Our results were in concordance with those of the studies which were reported by some researchers in other endemic states of India. ${ }^{24-27}$ For the anti-TH antibodies, an agglutinin titre of up-to 1:60 was discovered in the apparently healthy study population, whereas for the anti-TO antibodies, our result was lower (a titre of $1: 40$ ), which was in contrast to the reports of some other workers but it was in accordance with the reports of some previous studies. Several factors may have contributed to this discrepancy, because the differences in the antibody response may be due to the poorly standardized antigen preparation and the sharing of the antigen determinants with other Salmonellae. A widespread antibiotic abuse can dampen the antibody response, giving a low titre in the Widal test and a previous immunization with the TAB vaccine and technical differences may be the other contributory factors. It has been evident from the various studies which have been conducted across our country that the baseline titre is subjective variations, depending on the geographical area and the sanitary conditions of the region. Hence, the baseline titre of a particular area should be known. The probable reason for the low 
titre in our study could be the better health and hygiene conditions.

\section{CONCLUSION}

Based on the results of our study, it has been recommended that cut-off titre of 1:80 for anti-O antibodies and of 1:120 for the anti-H antibodies may be considered as diagnostic for enteric fever in Ajmer region of Rajasthan, India. So knowledge of prevalent endemic titre in a region needs to be periodically updated to interpret the significance of the titre as to the patient is indeed suffering from enteric fever or not.

\section{REFERENCES}

1. Chowta MN et al, Study of clinical profile and antibiotic response in typhoid fever Indian J. Med. Microbiol 23(2):125-7.2005

2. Pang T, Puthucheary SD. Significance and value of the Widal test in the diagnosis of typhoid fever in an endemic area. J Clin Pathol. 1983 Apr;36(4):471-5

3. Punia JN, Joshi RM, Gupta V, Arora RK. Determination of baseline Widal titres from Chandigarh. Indian J Med Microbiol. 2003 Apr-Jun; 21(2):144. PubMed PMID: 17643006.

4. Olopoinea L.A king AL, widal agglutination test 100 years later, still plagued by controversy, post gard med. J. 2000-76:82-84.

5. Gaddes AM et al, Imported infection . unexplained fever. VMJ. 1974:4:397-98, 1974.

6. Abraham G, Teklu B, Gedebu M, Selassie GH, Azene G. Diagnostic value of the Widal test. Trop Geogr Med. 1981 Dec;33(4):329-33

7. Tanyigna KB, Bello CS, Okeke N, Onwukeme KE. Comparison of blood, bone marrow aspirate, stool and urine cultures in the diagnosis of enteric fever. Niger J Med. 2001 Jan-Mar;10(1):214.

8. Peshattiwar P. Study of the baseline Widal titre amongst healthy individuals in Amlapuram, India. Journal of clinical and diagnostic research. 2012;6(3):416-7.

9. Park K. Park's textbook of preventive and social medicine. 18th ed. Jabalpur: M/S Banarsidas Bhanot 2005; 195-8.

10. Parry CM, Hien TT, Dougan G, White NJ, Farrar JJ. Typhoid fever. N Engl J Med 2002;347 (22):1770-80.

11. World Health Organization. Background documents: The diagnosis, treatment and prevention of typhoid fever. In: Communicable diasease surveillance and response vaccies and biologicals. Geneva WHO 2003; 1-18.

12. Patil AM, Kulkarni ML, Kulkarni AM. Baseline Widal titres in healthy children. Indian J Pediatr. 2007 Dec;74(12):1081-3.

13. Sudeepa Kumar M, Comparison of Salmonella Typhi and Paratyphi A Occurrence in a Tertiary Care Hospital, Journal of Clinical and Diagnostic Reasearch. 2013 Dec, Vol-7(12): 27242726.

14. Sultana S, Hossain MA, Paul SK, Kabir MR, Yesmin T, Maruf MA, Siddiqui ZR, Rahman SM, Hoque MR. Evaluation of TH agglutinin titres of Widal test in the diagnosis of typhoid fever. Mymen singh Med J. 2014 Jan;23(1):1-6

15. Jog et al, Enteric fever in Munbai- the clinical profile, the sensitivity patterns and the response to antimicrobials. general of association of physicians of India 2008:56:237-40.

16. Sharddha Prasad Gunjal, et al, Determination of Baseline Widal Titres Amongst Apparently Healthy Blood Donors in Ahmednagar, Maharashtra, India. J Clin Diagn Res. 2013 Dec; 7(12): 2709-2711.
17. Somily AM, Adam MH, Gad El Rab MO, Morshed MG, Shakoor Z. Detection of Salmonella Typhi agglutinins in sera of patients with other febrile illnesses and healthy individuals. Ann Afr Med. 2011 Jan-Mar;10(1):41-4. doi: 10.4103/1596-3519.76584.

18. Coovadia YM, Singh V, Bhana RH, Moodley N. Comparison of passive haemagglutination test with Widal agglutination test for serological diagnosis of typhoid fever in an endemic area. J Clin Pathol. 1986 Jun;39(6):680-3.

19. Gupta AK, Rao KM. A simple bactericidal antibody test for serodiagnosis of typhoid fever. J Immunol Methods. 1981;42(1):1215.

20. Pokhrel BM, Karmacharya R, Mishra SK, Koirala J. Distribution of antibody titer against Salmonella enterica among healthy individuals in Nepal. Ann Clin Microbiol Antimicrob. 2009 Jan 7;8:1. doi: 10.1186/1476-0711-8-1.

21. Zailani SB, Aboderin AO, Onipede AO. Effect of socio-economic status, age and sex on antibody titre profile to Salmonella Typhi I paratyphi in lle-lfe, Nigeria. Niger J Med. 2004 OctDec;13(4):383-7.

22. Adias TC, Jeremiah ZA, llesanmi AO. Distribution of antibodies to Salmonella in the sera of blood donors in the south-western region of Nigeria. Blood Transfus. 2010 Jul;8(3):163-9. doi: 10.2450/2009.0115-09.

23. Pal S, Prakash R, Juyal D, Sharma N, Rana A, Negi S. The baseline widal titre among the healthy individuals of the hilly areas in the garhwal region of uttarakhand, India. J Clin Diagn Res. $2013 \mathrm{Mar} ; 7(3): 437-40$.

24. Kataria VK, Bhai N, Mahawal BS, Roy RC. Determination of baseline Widal titre among apparently healthy population in Dehradun city. Journal of pharmacy and biological sciences. 2013;7(2):53-55.

25. Dutta S, Sur D, Manna B, Sen B, DebAK, Deen JL, et al. Evaluation of new generation serologic tests for the diagnosis of typhoid fever: data from a community based surveillance in Culcutta, India. Diagn Microbiol Infect Dis 2006;56(4):359-65.

26. Verma D, Kishore S, Siddique ME. Comparative evaluation of various tests for diagnosis of concurrent malaria and typhoid Fever in a tertiary care hospital of northern India. J Clin Diagn Res. 2014 May; 8(5) : DC41-4. doi: 10.7860/JCDR/2014/7745.4403.

27. Walia M, R Gaind, P Paul, R Metha, P Aggarwal, M Kalaivani et al. (2006) Age related clinical and microbiological characteristics of enteric fever in India. Trans R Soc Trop Med Hyg 100: 942948.

\section{Source of Support: Nil. Conflict of Interest: None Declared.}

Copyright: (c) the author(s) and publisher. IJMRP is an official publication of Ibn Sina Academy of Medieval Medicine \& Sciences, registered in 2001 under Indian Trusts Act, 1882.

This is an open access article distributed under the terms of the Creative Commons Attribution Non-commercial License, which permits unrestricted non-commercial use, distribution, and reproduction in any medium, provided the original work is properly cited.

Cite this article as: Laxman Ram Mohanpuria, Priyam Sharma, Prateek Kamble, Mohit Sharma, Geeta Parihar, Mahima Sharma. Determination of Significant Baseline Widal Titre amongst Health Personnel \& General Population of Ajmer City. Int J Med Res Prof. 2016; 2(3):169-73. 